\title{
Is the Relationship between Depression and C Reactive Protein Level Moderated by Social Support in Elderly?-Korean Social Life, Health, and Aging Project (KSHAP)
}

\author{
Nam Wook Hur ${ }^{1}$, Hyeon Chang Kim², Linda Waite ${ }^{3}$, and Yoosik Youm ${ }^{1 凶}$ \\ 'Department of Sociology, Yonsei University, Seoul, Republic of Korea \\ ${ }^{2}$ Department of Preventive Medicine, Yonsei University, Seoul, Republic of Korea \\ ${ }^{3}$ Department of Sociology, The University of Chicago, Chicago, IL, USA
}

Psychiatry Investig 2018;15(1):24-33

https://doi.org/10.4306/pi.2018.15.1.24

Unfortunately, the acknowledgements was incorrect in the original publication of this article. The correct acknowledgements is given below:

This study was supported by grants from the National Research Foundation of Korea funded by the Korean Government (NRF2014S1A3A204496).

(a) This is an Open Access article distributed under the terms of the Creative Commons Attribution Non-Commercial License (https://creativecommons.org/licenses/by$\mathrm{nc} / 4.0$ ) which permits unrestricted non-commercial use, distribution, and reproduction in any medium, provided the original work is properly cited. 